\title{
Pengaruh Tingkat Kematangan Buah terhadap Setek Basal Daun Mahkota Nanas (Ananas comosus (L.) Merr) Cv. Smooth Cayenne
}

\author{
The Effect of Fruit Maturity Stage on Crown Leaf Bud Cutting of Pineapple (ㅁnanas \\ comosus (L.) Merr) Cv. Smooth Cayenne
}

\author{
Husna Fatima Eprilian', M. Rahmad Suhartanto ${ }^{2,3 *}$, dan Endah Retno Palupi ${ }^{2}$
}

Diterima 18 Agustus 2018/Disetujui 02 April 2019

\begin{abstract}
Propagation method of pineapple that can be developed to increase the number of seedling is crown leaf bud cuttings method. The level of fruit maturity is thought to affect the successfull of crown leaf bud cuttings. This study was aimed to obtain information about the effect of fruit maturity level when taking the crown for cutting material for pineapple cv. Smooth Cayenne seedling production. The experiment used a RCBD with one factor, the factor is the level of maturity with four levels of treatment: Level of maturity 1 (K1): all eyes were green; maturity 2 (K2): yellow fruit eyes $<20 \%$; maturity 3 (K3): yellow fruit eyes 40-55\%; and maturity 4 (K4): yellow fruit eyes $>90 \%$; but the reddish-orange color $<20 \%$. Each treatment was repeated five times, so there were 20 experimental units. The results showed that the levels of endogenous auxin and cytokines were not different at all levels of maturity stage, but the $C / N$ ratio of $K 3$ and $K 4$ showed higher results. All maturity stage showed maximum bud formation at 4-6 WAP. The best fruit maturity level for pineapple seedling production with basal leaf crown cuttings is $K 4$ (yellow fruit eyes $>90 \%$, but reddish orange $<20 \%$ ). K4 had trend to produce higher survived, sprouted cutting and seedling dry weight. K4 showed the highest shoot dry weight and adequate seedling certification standards faster than other treatment..
\end{abstract}

Keyword: dormant bud, fast propagation, Smooth Cayyene, split crown, tropical fruit

\begin{abstract}
ABSTRAK
Metode pembibitan nanas yang dapat dikembangkan untuk meningkatkan jumlah bibit yang dapat dihasilkan adalah setek basal daun mahkota. Tingkat kematangan buah diduga berpengaruh terhadap tingkat keberhasilan setek basal daun. Penelitian ini bertujuan untuk mendapatkan informasi mengenai pengaruh tingkat kematangan buah pada saat pengambilan bahan setek untuk produksi bibit asal setek basal daun mahkota pada nanas cv. Smooth Cayenne. Percobaan menggunakan RKLT satu faktor, yaitu tingkat kematangan dengan empat taraf perlakuan: tingkat kematangan 1 (K1) : semua mata berwarna hijau; kematangan 2 (K2) : mata buah yang berwarna kuning < 20\%; kematangan 3 (K3) : mata buah yang berwarna kuning 40-55\%; kematangan 4 (K4): mata buah yang berwarna kuning $>90 \%$; tetapi yang berwarna jingga kemerahan $<20 \%$. Hasil penelitian menunjukkan kandungan auksin dan sitokinin endogen tidak berbeda pada semua tingkat kematangan, namun Nisbah C/N K3 dan K4 menunjukkan hasil lebih tinggi. Pada semua tingkat kematangan, terbentuknya tunas maksimum terjadi pada 4-6 MST. Tingkat kematangan buah terbaik untuk produksi bibit nanas dengan setek basal daun mahkota adalah K4 (mata buah yang berwarna kuning >90\%, tetapi yang berwarna jingga kemerahan <20\%). K4 memiliki kecenderunguan menghasilkan setek hidup, bertunas, dan berakar lebih tinggi. K4 menghasilkan bobot kering tunas tertinggi dan memenuhi standar bibit sertifikasi lebih cepat (52 MST).
\end{abstract}

Kata kunci: buah tropis, mata tunas dorman, perbanyakan cepat, split crown

\footnotetext{
${ }^{1}$ Program Studi Ilmu dan Teknologi Benih, Sekolah Pascasarjana, Institut Pertanian Bogor

J1. Meranti, Kampus IPB Darmaga, Bogor 16680, Indonesia.

${ }^{2}$ Departemen Agronomi dan Hortikultura, Fakultas Pertanian, Institut Pertanian Bogor

Jl. Meranti, Kampus IPB Darmaga, Bogor 16680, Indonesia.

${ }^{3}$ Pusat Kajian Hortikultura Tropika, LPPM-Institut Pertanian Bogor

Jl. Raya Padjajaran, Kampus IPB Baranangsiang, Bogor 16143, Indonesia

E-mail : tantosuhartanto63@gmail.com (*Penulis korespondensi)
} 


\section{PENDAHULUAN}

Nanas merupakan salah satu komoditas unggul Indonesia, namun saat ini belum dikembangkan secara optimal. Hal tersebut tercermin dari produksi nanas yang berfluktuasi tiap tahunnya (FAOSTAT, 2016). Salah satu kendala pengembangan agroindustri nanas yang diduga menyebabkan fluktuasi produksi adalah terbatasnya penyediaan bibit siap tanam baik dalam hal kuantitas maupun kualitas (Elfiani dan Ariyati, 2012).

Bahan perbanyakan nanas yang biasa digunakan adalah mahkota buah (crown), tunas buah (slip), dan tunas batang (sucker) (Magersa, 2017). Bibit yang diperoleh dari bagian-bagian tersebut jumlahnya terbatas, sehingga tidak memenuhi kebutuhan bibit dalam skala besar. Smooth Cayenne adalah salah satu jenis nanas yang banyak di budidayakan petani Indonesia. Contoh nanas jenis Smooth Cayenne adalah nanas Subang dan nanas PK-1. Smooth Cayenne hanya mampu menghasilkan satu atau dua anakan per tanaman dan jarang lebih dari tiga anakan (Py et al.,1987). Penanaman dalam skala luas akan terhambat karena rendahnya anakan yang dihasilkan, sedangkan untuk mendapatkan produksi nanas yang optimal dibutuhkan minimal 40000 bibit ha $^{-1}$ (PKBT, 2008).

Salah satu metode pembibitan yang dapat dikembangkan untuk meningkatkan jumlah bibit yang dihasilkan adalah setek basal daun mahkota. Penanaman menggunakan satu mahkota utuh hanya akan menghasilkam satu tanaman (Shiyam et al., 2016). Jika menggunakan setek basal daun, maka satu mahkota nanas Smooth Cayyene dapat menghasilkan 23 - 32 bibit (Tassew, 2014).

Selama ini bahan setek basal daun mahkota diambil ketika buah sudah matang. Belum banyak penelitian yang mempelajari pengaruh kematangan buah terhadap keberhasilan setek basal daun mahkota. Bahan setek yang berasal dari tingkat kematangan buah yang berbeda diduga memiliki kandungan zat pengatur tumbuh yang berbeda. Kadar hormon endogen yang berbeda pada setiap eksplan akan mempengaruhi pertumbuhan dan perkembangan setek (Putri dan Danu, 2014). Penggunaan batang muda dan tua pada setek batang nanas tidak berpengaruh terhadap keberhasilan setek bertunas (Nasution dan Hadiati, 2011), namun pada setek batang nanas
Smooth Cayenne kultivar 'N-67-10' yang diberi $5 \mathrm{mg} \mathrm{L}^{-1}$ CPPU, penggunaan batang tua menunjukkan persen setek bertunas lebih tinggi (96.1\%) dibandingkan batang muda $(68.5 \%)$ (Adaniya et al., 2004).

Penelitian ini bertujuan untuk mendapatkan informasi mengenai pengaruh tingkat kematangan buah pada saat pengambilan setek terhadap keberhasilan produksi bibit asal setek basal daun mahkota pada nanas Smooth Cayenne.

\section{BAHAN DAN METODE}

Penanaman setek dilakukan di Screen House Kebun Percobaan Leuwikopo, Departemen Agronomi dan Hortikultura, Institut Pertanian Bogor pada September 2017 sampai Februari 2018. Analisis hormon endogen dan Nisbah $\mathrm{C} / \mathrm{N}$ dilakukan di Laboratorium Indonesian Center for Biodiversity and Biotechnology (ICBB), Bogor.

Percobaan ini dirancang dalam rancangan kelompok lengkap teracak (RKLT) satu faktor yaitu tingkat kematangan dengan empat taraf perlakuan. Percobaan ini dirancang dalam rancangan acak lengkap (RAL) satu faktor, yaitu tingkat kematangan buah dengan empat taraf perlakuan, yaitu: tingkat kematangan 1 (K1) : mata berwarna hijau 100\% $( \pm 180$ hari setelah induksi pembungaan); Kematangan 2 (K2) : mata buah yang berwarna kuning < 20\% ( \pm 185 HSP); kematangan 3 (K3) : mata buah yang berwarna kuning $40-55 \%$ $( \pm 190$ HSP); dan kematangan 4 (K4) : mata buah yang berwarna kuning > 90\% dengan warna jingga kemerahan $<20 \%$ ( \pm 195 HSP).

Tiap perlakuan diulang sebanyak lima kali, sehingga terdapat 20 satuan percobaan. Setiap satu satuan percobaan terdiri atas 25 setek basal daun tanaman nanas. Setek yang digunakan berasal dari seluruh bagian mahkota (atas, tengah, dan bawah). Daun mahkota diikutsertakan dalam keadaan utuh.

Media tanam yang digunakan adalah cocopeat dan kompos dengan perbandingan $(1: 1 \mathrm{v} / \mathrm{v})$ yang terlebih dahulu disterilisasi dengan cara mengukus media selama 4 jam. Setelah sterilisasi, media dibasahi sampai kapasitas lapang. Bak persemaian yang digunakan terbuat dari kotak plastik yang diberi lubang. Ketebalan media tanam sekitar $10 \mathrm{~cm}$. 


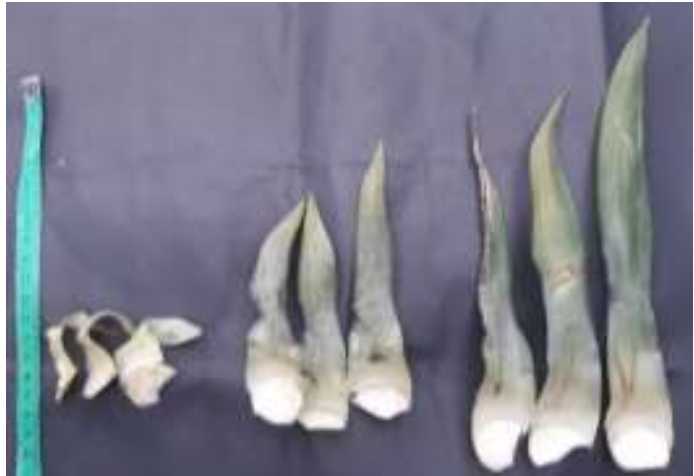

Gambar 1. Potongan setek basal daun mahkota nanas Cv. Smooth Cayenne

Setek yang digunakan adalah potongan bagian basal daun mahkota dengan mengikutsertakan mata tunas dorman dan sedikit bagian meristem batangnya (Gambar 1). Pemotongan dilakukan dengan menggunakan cutter. Potongan setek kemudian disterilisasi dengan cara direndam dalam larutan $\mathrm{NaClO}$ $10 \%$ selama 10 menit kemudian direndalm kembali dalam $\mathrm{NaClO} 5 \%$ selama 10 menit. Setelah sterilisasi setek kemudian dibilas dengan air dan direndan dalam larutan fungisida berbahan aktif propinep $70 \%$ konsentrasi $2 \mathrm{~g} \mathrm{~L}^{-1}$ air selama 10 menit untuk menghindari serangan cendawan, kemudian setek dikeringanginkan selama 5 menit. Setelah itu, setek ditanam dalam bak persemaian yang telah berisi media kemudian diletakkan dalam screen house. Pada 10 MST, setek memasuki tahap pembibitan dan dipindahkan ke polibag sampai 20 MST.

Kegiatan pemeliharaan meliputi penyiraman, penyiangan gulma, serta pengendalian hama dan penyakit. Penyiraman dilakukan 1 atau 2 minggu sekali. Penyiangan gulma dilakukan secara manual. Pencegahan dan pengendalian hama dan penyakit: fungisida berbahan aktif Propinep 70\% dan Benomil 50\% dengan konsentrasi $2 \mathrm{~g} \mathrm{~L}^{-1}$ air, serta insektisida berbahan aktif Deltametrin $25 \mathrm{~g} \mathrm{~L}^{-1}$ dengan konsentrasi $2 \mathrm{~mL} \mathrm{~L}^{-1}$ air.

Pengamatan meliputi analisis kandungan nisbah $\mathrm{C} / \mathrm{N}$ serta auksin dan sitokinin endogen di Laboratorium Indonesian Center for Biodiversity and Biotechnology (ICBB), Bogor. Analisis dilakukan sebelum penanaman terhadap setek basal daun untuk mengetahui kandungan auksin dan sitokinin endogen dari empat tingkat kematangan buah berbeda. Sampel yang digunakan terdiri atas beberapa setek basal daun yang dipilih secara acak, sampel kemudian dianalisis secara komposit.
Jumlah sampel untuk tiap kematangan adalah dua ulangan. Analisis kandungan C-organik menggunakan metode gravimetri dan analisis kandungan $\mathrm{N}$-total menggunakan metode Kjeldahl dilakukan untuk mengetahui nisbah C/N. Sementara itu, analisis auksin dan sitokinin secara kuantitatif menggunakan metode HPLC.

Peubah pengamatan lain terdiri atas: 1) Setek hidup (\%). Setek dikatakan hidup jika setek masih segar (tidak busuk). 2) Setek bertunas (\%). Setek dikatakan bertunas jika setek masih segar dan memiliki tunas dengan tinggi minimal $0.5 \mathrm{~cm} .3)$ Pertambahan setek bertunas (\%). Persentase pertambahan setek bertunas setiap minggu. 4) Setek berakar (\%). Setek dikatakan berakar jika setek masih segar dan memiliki akar minimal $1 \mathrm{~cm}$. 5) Tinggi bibit $(\mathrm{cm})$. Tinggi diukur dari pangkal sampai ujung daun tertinggi. 6) Jumlah daun (helai). Daun yang dihitung adalah daun yang masih menguncup maupun yang sudah membuka sempurna. 7) Bobot kering tunas (g). Tunas dipisahkan dari akar, kemudian dibersihkan dari media tanam. Pengeringan dilakukan dengan menggunakan oven $60{ }^{\circ} \mathrm{C} 72$ jam. Peubah 1-3 diamati pada 2-10 MST (fase persemaian), sedangkan peubah 2-7 diamati pada 20 MST (akhir fase pembibitan).

Analisis data menggunakan analisis korelasi menggunakan software minitab, serta analisis varians (ANOVA) pada taraf $\alpha=5 \%$, dan data yang menunjukkan perbedaan nyata diuji lanjut dengan Duncan's Multiple Range Test (DMRT) pada taraf $\alpha=5 \%$ dengan menggunakan software SAS University Edition.

\section{HASIL DAN PEMBAHASAN}

\section{Status Hormon dan Nisbah $\mathrm{C} / \mathrm{N}$}

Kandungan C-organik tidak dipengaruhi oleh tingkat kematangan (Tabel 1). Hasil analisis menunjukkan tingkat kematangan mempengaruhi N-Total dan Nisbah C/N. Ntotal yang terkandung dalam K1 dan K2 lebih tinggi dibandingkan $\mathrm{K} 3$ dan $\mathrm{K} 4$, sehingga menyebabkan nilai Nisbah C/N K3 dan K4 lebih tinggi dari $\mathrm{K} 1$ dan $\mathrm{K} 2$. Hal ini menunjukkan bahwa penggunaan jenis bahan tanam yang berbeda memiliki variasi komposisi senyawa kimia yang berbeda (Hartmann et al., 2010). 
Tabel 1. Status hormon endogen serta Nisbah C/N pada tingkat kematangan buah berbeda

\begin{tabular}{cccccc}
\hline $\begin{array}{c}\text { Tingkat } \\
\text { Kematangan }\end{array}$ & $\begin{array}{c}\text { C-Organik } \\
(\%)\end{array}$ & $\begin{array}{c}\text { N-Total } \\
(\%)\end{array}$ & $\begin{array}{c}\text { Nisbah } \\
\mathrm{C} / \mathrm{N}\end{array}$ & $\begin{array}{c}\text { IAA } \\
(\mathrm{ppm})\end{array}$ & $\begin{array}{c}\text { Zeatin } \\
(\mathrm{ppm})\end{array}$ \\
\hline K1 & 41.30 & $0.51 \mathrm{a}$ & $82.28 \mathrm{~b}$ & 76.96 & 51.80 \\
K2 & 41.39 & $0.60 \mathrm{a}$ & $69.65 \mathrm{~b}$ & 77.42 & 58.04 \\
K3 & 41.25 & $0.23 \mathrm{~b}$ & $182.96 \mathrm{a}$ & 78.04 & 55.60 \\
K4 & 41.40 & $0.33 \mathrm{~b}$ & $128.50 \mathrm{ab}$ & 81.79 & 51.30 \\
\hline KK $(\%)$ & 2.08 & 12.35 & 21.44 & 7.68 & 5.29 \\
\hline
\end{tabular}

Keterangan: $\mathrm{KI}=$ tingkat kematangan 1: semua mata buah berwarna hijau, K2= tingkat kematangan buah 2: mata buah yang berwarna kuning $<20 \%, \mathrm{~K} 3=$ tingkat kematangan 3 : mata buah yang berwarna kuning $40-55 \%$, $\mathrm{K} 4=$ tingkat kematangan 4: mata buah yang berwarna kuning $>90 \%$, tetapi yang berwarna jingga kemerahan $<20 \%$. Angka-angka pada kolom yang sama yang diikuti oleh huruf yang sama tidak berbeda nyata pada taraf DMRT $\alpha=5 \%$.

$\mathrm{C} / \mathrm{N}$ rasio adalah salah satu faktor yang memengaruhi perakaran setek, namun nilai $\mathrm{C} / \mathrm{N}$ rasio terbaik untuk setek tidak dapat diperkirakan secara pasti, karena nilai $\mathrm{C} / \mathrm{N}$ rasio tiap tanaman berbeda (Danu, 2011). Menurut Bhardwaj dan Mishra (2005) setek yang memiliki kandungan gula, karbohidrat total, dan aktifitas enzim peroxidase yang tinggi dengan kandungan $\mathrm{N}$ yang rendah akan memiliki perakaran yang baik.

Jenis dan umur bahan setek serta kandungan zat pengatur tumbuh endogen (ZPT) merupakan faktor yang mempengaruhi keberhasilan setek (Hartmann et al., 2010). Pada penelitian ini tingkat kematangan tidak mempengaruhi ZPT endogen (IAA dan Zeatin) (Tabel 1). Hasil penelitian menunjukkan adanya kecenderungan peningkatan IAA seiring dengan semakin tingginya tingkat kematangan. Keadaan serupa ditemukan pada penelitian Putri dan Danu (2014), pada setek kemenyan semakin tua umur bahan setek, kandungan auksin cenderung mengalami peningkatan dan kemampuan setek berakar pun meningkat.

\section{Produksi Bibit}

\section{Setek hidup}

Setek dikatakan hidup jika mata tunas masih segar, tidak busuk atau kering (Gambar 2a). Secara umum persentase setek segar mengalami penurunan seiring dengan semakin lamanya waktu penanaman. Penurunan paling signifikan terjadi pada awal masa penanaman (Tabel 2). Keragaan setek basal daun yang segar, busuk atau kering pada fase persemaian seperti terlihat pada Gambar 2b dan 2c.

Tingkat kematangan mempengaruhi persentase setek hidup pada 2-3 MST (Tabel 2).
K3 dan K4 menunjukkan persentase setek hidup yang lebih tinggi. Kemampuan adaptasi merupakah salah satu faktor yang mempengaruhi persentase setek hidup (Apriani dan Suhartanto, 2014). Setek hidup yang tinggi dapat mencerminkan kemampuann setek beradaptasi dengan lingkungan dengan baik. Hal ini menunjukkan bahwa untuk menghasilkan persentase setek segar yang tinggi, mahkota harus dipanen ketika buah minimal 40\% menguning (tingkat kematangan 3 dan 4).

Pada tingkat kematangan $\mathrm{K} 3$ dan $\mathrm{K} 4$, kandungan $\mathrm{N}$ total berkisar antara $0.23-0.33 \%$ dengan $\mathrm{C} / \mathrm{N}$ sebesar 128.50-182.96, angka tersebut berbeda nyata dengan tingkat kematangan yang lebih muda (K1 dan K2) (Tabel 1). Kondisi tersebut kemungkinan merupakan kondisi optimum untuk setek beradaptasi dengan lingkungan pada awal penanaman sehingga memiliki persentase hidup lebih tinggi (Tabel 2). Hal serupa pun terjadi pada setek herba Paeonia 'Yang Fei Chu Yu'dengan kandungan nisbah $\mathrm{C} / \mathrm{N}$ tertinggi menunjukkan persentase hidup $90 \%$, sedangkan setek dengan $\mathrm{C} / \mathrm{N}$ lebih rendah hanya mencapai $80 \%$ (Guo et al., 2008).
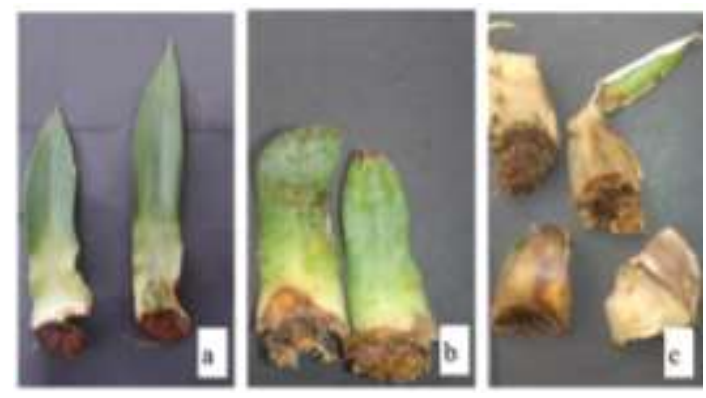

Gambar 2. Setek basal daun mahkota nanas: (a) segar, (b) busuk, dan (c) kering. 
Tabel 2. Pengaruh tingkat kematangan buah terhadap persentase setek hidup pada (\%)

\begin{tabular}{cccccccccc}
\hline Tingkat & \multicolumn{7}{c}{ Minggu Setelah Tanam (MST) } \\
\cline { 2 - 10 } Kematangan & 2 & 3 & 4 & 5 & 6 & 7 & 8 & 9 & 10 \\
\hline K1 & $48.0 \mathrm{~b}$ & $41.6 \mathrm{~b}$ & 38.4 & 32.8 & 32.8 & 32.0 & 32.0 & 31.2 & 30.4 \\
K2 & $45.6 \mathrm{~b}$ & $44.8 \mathrm{~b}$ & 44.8 & 44.0 & 43.2 & 42.4 & 42.4 & 41.6 & 41.6 \\
K3 & $60.8 \mathrm{a}$ & $58.4 \mathrm{ab}$ & 53.6 & 52.8 & 50.4 & 48.8 & 48.8 & 48.8 & 46.4 \\
K4 & $79.2 \mathrm{a}$ & $70.4 \mathrm{a}$ & 68.0 & 64.8 & 62.4 & 61.6 & 61.6 & 60.0 & $60.0^{\mathrm{t}}$ \\
\hline KK $(\%)$ & $16.3^{\mathrm{t}}$ & $16.4^{\mathrm{t}}$ & $18.1^{\mathrm{t}}$ & $19.5^{\mathrm{t}}$ & $20.1^{\mathrm{t}}$ & $20.3^{\mathrm{t}}$ & $20.3^{\mathrm{t}}$ & $19.0^{\mathrm{t}}$ & $20.1^{\mathrm{t}}$ \\
\hline
\end{tabular}

Keterangan: KI= tingkat kematangan 1: semua mata buah berwarna hijau, K2= tingkat kematangan buah 2: mata buah yang berwarna kuning $<20 \%, \mathrm{~K} 3=$ tingkat kematangan 3 : mata buah yang berwarna kuning $40-55 \%$, K4= tingkat kematangan 4 : mata buah yang berwarna kuning > 90\%, tetapi yang berwarna jingga kemerahan < $20 \%$. Angka-angka pada kolom yang sama yang diikuti oleh huruf yang sama tidak berbeda pada taraf DMRT $\alpha=5 \% .{ }^{\mathrm{t}}=$ transformasi $\sqrt{x+0.5}$.

\section{Setek bertunas}

Munculnya tunas diawali dengan adanya penonjolan pada mata tunas dorman. Mata tunas yang awalnya berwarna putih kemudian berubah warna menjadi kehijauan dan tumbuh membentuk tunas (Oktaviana et al., 2015; Rupina et al., 2015). Setek bertunas dapat dijadikan salah satu indikasi bahwa mata tunas sudah mengalami pecah dormansi. Djamhari (2010) mengatakan bahwa pada rimpang temulawak, pecahnya dormansi ditandai dengan tumbuhnya tunas pada rimpang.

Tingkat kematangan buah saat pengambilan mahkota untuk bahan setek mempengaruhi persentase setek bertunas pada 4 sampai 6 MST (Tabel 3). Pada 4-6 MST K4 menunjukkan persentase tertinggi. Ada kecenderungan semakin tinggi tingkat kematangan buah, maka semakin tinggi pula persentase setek bertunas yang mengindikasikan jumlah bibit nanas yang dihasilkan akan semakin banyak.

Bahan yang berasal dari setek masih muda (K1 dan K2) mengandung unsur nitrogen yang relatif tinggi (Tabel 1). Bahan setek yang memiliki kandungan nitrogen tinggi menghasilkan persentase setek tumbuh dan bertunas yang rendah pada setek kranji (Danu et al., 2011). Karbohidrat pada setek berguna untuk regenerasi akar, tetapi dalam jumlah kecil. Nitrogen diperlukan untuk sintesis asam nukleat dan protein. Nitrogen yang sangat rendah menyebabkan berkurangnya vigor, sedangkan nitrogen yang tinggi menyebabkan kelebihan energi yang tidak menguntungkan untuk setek (Hartmann et al., 2010). Pada minggu 7-10 MST persentase setek hidup tidak berpengaruh, hal ini terjadi kemungkinan karena sudah banyak faktor lain yang mempengaruhi, selain dari tingkat kematangan.

Tabel 3. Pengaruh tingkat kematangan buah terhadap persentase setek bertunas setek basal daun mahkota nanas Cv. Smooth Cayenne (\%)

\begin{tabular}{crrrrrrrrc}
\hline Tingkat & \multicolumn{8}{c}{ Minggu Setelah Tanam (MST) } \\
\cline { 2 - 10 } Kematangan & 2 & 3 & 4 & 5 & 6 & 7 & 8 & 9 & 10 \\
\hline K1 & 0.0 & 0.0 & $8.8 \mathrm{~b}$ & $24.0 \mathrm{~b}$ & $28.8 \mathrm{~b}$ & 32.8 & 31.2 & 32.0 & 30.4 \\
K2 & 0.0 & 1.6 & $8.0 \mathrm{~b}$ & $24.0 \mathrm{~b}$ & $36.8 \mathrm{~b}$ & 40.8 & 42.4 & 42.4 & 41.6 \\
K3 & 0.0 & 1.6 & $4.8 \mathrm{~b}$ & $24.0 \mathrm{~b}$ & $42.4 \mathrm{ab}$ & 46.4 & 47.2 & 47.2 & 46.4 \\
K4 & 0.0 & 0.8 & $16.0 \mathrm{a}$ & $45.6 \mathrm{a}$ & $60.8 \mathrm{a}$ & 60.8 & 60.8 & 60.8 & 60.8 \\
\hline KK $(\%)$ & 0.0 & $69.0^{\mathrm{t}}$ & $25.1^{\mathrm{t}}$ & $24.3^{\mathrm{t}}$ & $17.4^{\mathrm{t}}$ & $19.7^{\mathrm{t}}$ & $20.4^{\mathrm{t}}$ & $19.6^{\mathrm{t}}$ & $19.6^{\mathrm{t}}$ \\
\hline
\end{tabular}

Keterangan: $\mathrm{KI}=$ tingkat kematangan 1: semua mata buah berwarna hijau, K2= tingkat kematangan buah 2: mata buah yang berwarna kuning $<20 \%, \mathrm{~K} 3=$ tingkat kematangan 3: mata buah yang berwarna kuning $40-55 \%$, $\mathrm{K} 4=$ tingkat kematangan 4: mata buah yang berwarna kuning $>90 \%$, tetapi yang berwarna jingga kemerahan $<20 \%$. Angka-angka pada kolom yang sama yang diikuti oleh huruf yang sama tidak berbeda nyata pada taraf DMRT $\alpha=5 \%$. ${ }^{\mathrm{t}}=$ transformasi $\sqrt{x+0.5}$. 
Tunas dorman mulai tumbuh pada 3 MST (kecuali K1), minggu selanjutnya pertambahan setek bertunas terus meningkat dan mencapai maksimal pada 5 MST (Gambar 3). Minggu efektif setek bertunas terjadi pada 4-6 MST. Fenomena ini sejalan dengan penelitian Weerasinghe dan Siriwarfana (2006) yang menyatakan bahwa pada 4 sampai 5 MST merupakan fase dimana pertumbuhan tunas maksimal dimulai, atau disebut dengan fase sucker emergence.

Waktu yang diperlukan tiap setek bertunas bervariasi. Hal ini terlihat dari masih adanya setek yang baru bertunas pada akhir pengamatan (Gambar 3). Keberagaman pertumbuhan pada perbanyakan vegetatif nanas merupakan hal biasa terjadi. Agogbua dan Osuji (2011) mengungkapkan bahwa bibit yang dihasilkan dari teknik split crown nanas tetap bervariasi meskipun berasal dari mahkota dengan umur dan ukuran yang sama. Waktu setek bertunas yang bervariasi terjadi karena pada penelitian ini bahan setek yang digunakan berasal dari seluruh bagian mahkota (bawah, tengah, dan ujung). Penelitian Luqmantoro et al. (2017) pada setek batang nanas menunjukkan persentase bertunas setek yang berasal dari batang bagian atas dapat mencapai $60.57 \%$, sedangkan setek yang berasal dari batang bagian bawah hanya mencapai $14.57 \%$. Hal ini menunjukkan bahwa posisi asal bahan setek
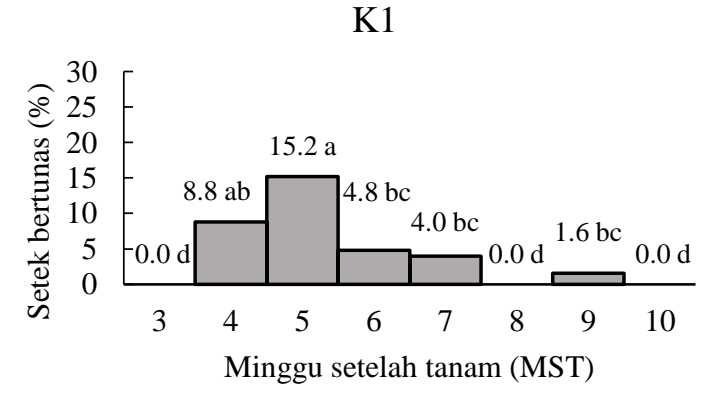

K3

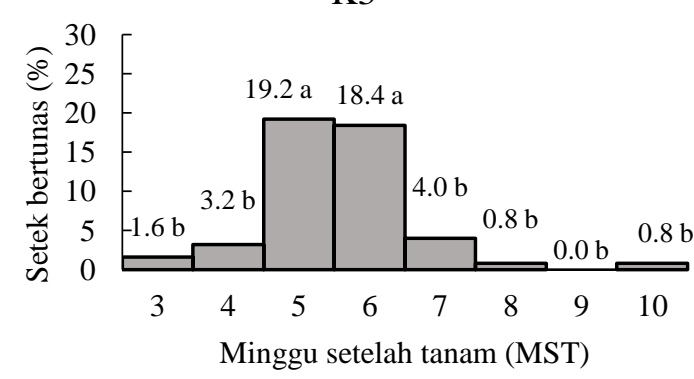

mempengaruhi kemampuan setek untuk bertunas. Oleh karena itu, sebaiknya untuk menghasilkan bibit yang seragam, setek harus dikelompokkan berdasarkan bagiannya pada mahkota.

\section{Setek berakar}

Tingkat kematangan buah tidak berpengaruh nyata terhadap setek berakar, namun cenderung semakin tinggi dengan semakin tingginya tingkat kematangan buah (Tabel 3). Hal ini disebabkan kandungan IAA pada setek cenderung mengalami peningkatan seiring meningkatnya kematangan buah (Tabel 1). Hasil analisis menunjukkan bahwa IAA berkorelasi kuat dengan persentase setek berakar pada 10 MST $(r=0.793)$ dan 20 MST $(\mathrm{r}=0.936)$ (Tabel 4). Semakin tinggi kandungan auksin, persentase setek berakar semakin meningkat, karena IAA (auksin endogen) merupakan salah satu jenis auksin yang berperan dalam menginduksi primordia akar (Ling dan Zhong, 2012). Hasil serupa ditemui Putri dan Danu (2014) pada setek kemanyan yang menyebutkan bahwa bahan setek dari bibit umur 4 bulan (kandungan auksin 0.0088\%) menghasilkan persentase setek berakar tertinggi $(83.54 \%)$ dibandingkan dengan bibit umur 1 dan 2 bulan (kandungan auksin $(0.0046 \%$ dan $0.0064 \%)$ dengan persentase setek berakar $26.5 \%$ dan $71.4 \%$.
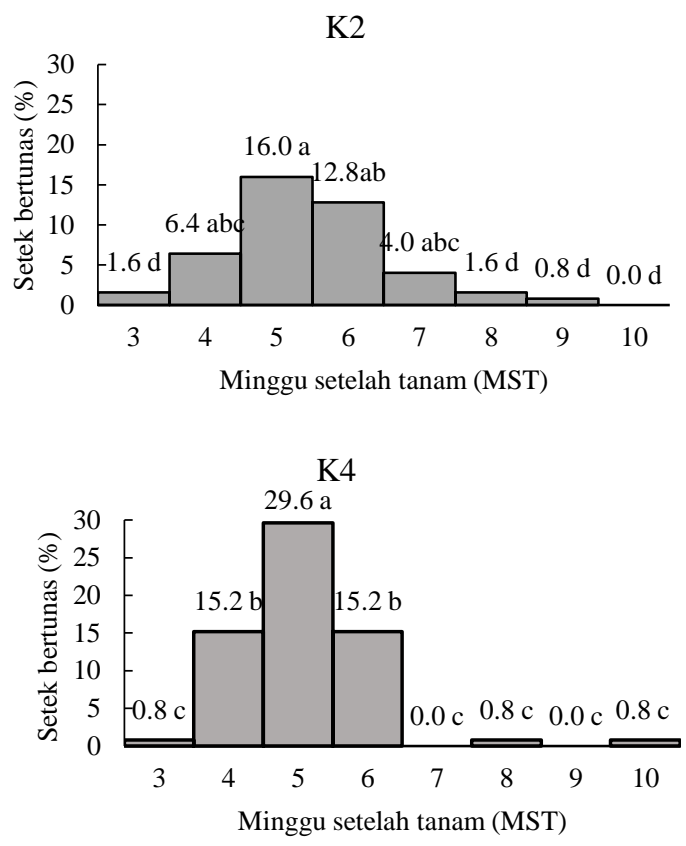

Gambar 3. Persentase pertambahan setek bertunas pada 2-10 MST pada setek basal daun mahkota nanas Cv. Smooth Cayenne asal tingkat kemasakaan berbeda. 
Selain dipengaruhi oleh kandungan auksin, kemampuan setek berakar diduga dipengaruhi oleh keseimbangan kandungan karbohidrat dan nitrogen dalam setek. Nisbah $\mathrm{C} / \mathrm{N}$ penting untuk menentukan periode optimum pemanenan bahan tanam dari tanaman induk pada setek $R$. multiflora karena penurunan nisbah $\mathrm{C} / \mathrm{N}$ menyebabkan penurunan kemampuan berakar (Hambrick, 1991). Hal berbeda terjadi pada setek Ulmus villosa, nisbah $\mathrm{C} / \mathrm{N}$ tidak dapat dijadikan indikator karena tidak berkorelasi dengan persentase berakar (Bhardwaj dan Mishra, 2005).

Kandungan $\mathrm{C}$ dan $\mathrm{N}$ serta nisbah $\mathrm{C} / \mathrm{N}$ tidak berkorelasi kuat dengan persentase setek berakar dalam penelitian ini (Tabel 7), namun $\mathrm{K} 4$ dengan $\mathrm{C} / \mathrm{N}$ ratio bahan setek sebesar 128.50 dengan $\mathrm{N}$-total $0.33 \%$ dan $\mathrm{C}$-organik $41.40 \%$ menunjukkan kecenderungan setek berakar yang tinggi dibandingkan tingkat kematangan lain (Tabel 5). Nisbah $\mathrm{C} / \mathrm{N}$ tersebut diduga merupakan kondisi optimum untuk perakaran setek. Menurut Bhardwaj dan Mishra (2005) bahan setek yang memiliki kandungan gula, karbohidrat total, dan aktivitas enzim peroxidase yang tinggi dengan kandungan $\mathrm{N}$ yang rendah akan memiliki perakaran yang baik. Enzim peroksidase adalah enzim kunci dalam proses pembentukan akar. Aktivitas enzim peroksidase yang tinggi secara biokimia menandakan adanya kecenderungan pembentukkan akar yang tinggi.

Berdasarkan peubah produksi tingkat kematangan hanya berpengaruh pada fase awal penanaman setek. Namun ada kecenderungan semakin tinggi tingkat kematangan persentase setek hidup, bertunas dan berakar semakin tinggi.

\section{Mutu Bibit}

\section{Tinggi bibit}

Tingkat kematangan buah tidak mempengaruhi tinggi bibit pada 20 MST (Tabel 5). Menurut Direktorat Perbenihan Hortikultura (2016) salah satu kriteria sertifikasi bibit nanas asal setek basal daun adalah memiliki tinggi minimal $25 \mathrm{~cm}$. Sampai dengan akhir penelitian (20 MST) bibit yang dihasilkan dari seluruh perlakuan hanya mencapai tinggi sekitar sekitar $8-9 \mathrm{~cm}$ (Tabel 5). Tinggi bibit yang dihasilkan belum mencapai tinggi minimal bibit untuk sertifikasi. Data ini menunjukkan bahwa waktu pembibitan nanas perlu diperpanjang agar dapat mencapai standar. Hasil pengamatan tinggi bibit penelitian ini masih dalam batas wajar, karena pada penelitian serupa yang dilakukan Naibaho (2012) bibit asal setek basal daun mahkota nanas Cv. Smooth yang tidak diberi aplikasi ZPT memiliki tinggi bibit rata-rata hanya mencapai 8-9 $\mathrm{cm}$ pada $20 \mathrm{MST}$.

Tabel 4. Pengaruh tingkat kematangan buah terhadap setek berakar (\%) pada setek basal daun mahkota nanas Cv. Smooth Cayenne

\begin{tabular}{cc}
\hline Tingkat Kematangan & Setek Berakar $(\%)$ \\
\hline K1 & 31.2 \\
K2 & 40.0 \\
K3 & 46.4 \\
K4 & 59.2 \\
\hline KK $(\%)$ & 34.12
\end{tabular}

Keterangan: $\mathrm{KI}=$ tingkat kematangan 1: semua mata buah berwarna hijau, $\mathrm{K} 2=$ tingkat kematangan buah 2: mata buah yang berwarna kuning $<20 \%, \mathrm{~K} 3=$ tingkat kematangan 3: mata buah yang berwarna kuning $40-55 \%$, K4= tingkat kematangan 4: mata buah yang berwarna kuning > 90\% dengan jingga kemerahan < $20 \%$. MST=minggu setelah tanam. Angka-angka pada kolom yang sama yang diikuti oleh huruf yang sama tidak berbeda nyata pada taraf DMRT $\alpha=5 \%$.

Tabel 5. Koefisien korelasi (r) antara auksin dan Nisbah C/N dengan setek berakar dan bobot kering akar pada setek basal daun mahkota nanas $\mathrm{Cv}$. Smooth Cayenne

\begin{tabular}{cc}
\hline Peubah & Setek Berakar (\%) \\
\hline Auksin & $0.936 *$ \\
C-organik & 0.396 \\
N-total & -0.622 \\
Nisbah C/N & 0.533 \\
\hline
\end{tabular}

Keterangan: *=berpengaruh nyata pada taraf $\alpha=5 \%$. MST $=$ minggu setelah tanam 
Hasil ekstrapolasi data tinggi bibit menunjukkan bahwa bibit asal tingkat kematangan 1 sampai 4 berturut-turut mencapai tinggi $25 \mathrm{~cm}$ pada $58,56,56$, dan 52 MST. Hasil ekstrapolasi data menunjukkan bibit asal tingkat kematangan 4 mencapai standar mutu bibit cepat dibandingkan tingkat kematangan lain, meskipun pada 20 MST tingkat kematangan tidak mempengaruhi tinggi bibit.

\section{Jumlah daun}

Pengamatan pada 20 MST menunjukkan bahwa jumlah daun yang dihasilkan oleh bibit setek basal daun asal batang pada seluruh tingkat kematangan berkisar antara 9-10 helai daun per tanaman (Tabel 6). Jumlah daun minimal yang dibutuhkan untuk bibit yang siap tanam adalah delapan helai daun per tanaman (PKBT, 2008). Hal ini menunjukkan bahwa jumlah daun yang dihasilkan sudah mencapai jumlah daun minimal untuk bibit nanas siap tanam.

\section{Bobot kering tunas}

Bobot kering tunas dapat dijadikan indikator vigor dan menunjukkan efektivitas bibit menyerap hara. Menurut Gardner dan Pearce (1991) bobot kering merupakan hasil akumulasi senyawa organik yang berhasil disintesis oleh tanaman melalui proses fotosintesis. Tabel 6 memperlihatkan bahwa tingkat kematangan buah mempengaruhi bobot kering tunas. K4 menunjukkan bobot kering tunas tertinggi dibandingkan tingkat kematangan lain. Hal ini menunjukkan setek K4 mengalami pertumbuhan tunas lebih cepat dibandingkan tikat kematangan lain. Bobot kering tunas yang tinggi menunjukkan bahwa bibit asal tingkat kematangan 4 memiliki mutu yang lebih tinggi.

Berdasarkan peubah mutu di pembibitan hanya bobot kering tunas yang menunjukkan bahwa K4 menghasilkan bibit dengan mutu lebih tinggi dibandingkan dengan tingkat kematangan yang lain. Sementara peubah mutu bibit yang lain tidak berbeda nyata antar tingkat kematangan, namun bibit asal $\mathrm{K} 4$ dapat memenuhi standar bibit sertifikasi lebih cepat dibandingkan tingkat kematangan lain, sehingga dapat membuat waktu produksi bibit lebih cepat.

Tabel 6. Pengaruh tingkat kematangan buah terhadap tinggi tunas, jumlah daun dan bobot kering tunas setek basal daun mahkota nanas Cv. Smooth Cayenne pada 20 MST.

\begin{tabular}{cccc}
\hline Tingkat Kematangan & $\begin{array}{c}\text { Tinggi Bibit } \\
(\mathrm{cm})\end{array}$ & $\begin{array}{c}\text { Jumlah Daun } \\
\text { (helai) }\end{array}$ & $\begin{array}{c}\text { Bobot Kering Tunas } \\
(\mathrm{g})\end{array}$ \\
\hline K1 & 8.0 & 9.6 & $0.2500 \mathrm{c}$ \\
K2 & 8.6 & 10.5 & $0.3367 \mathrm{~b}$ \\
K3 & 8.7 & 10.0 & $0.3142 \mathrm{~b}$ \\
K4 & 8.9 & 10.7 & $0.4058 \mathrm{a}$ \\
\hline KK $(\%)$ & 9.9 & 5.3 & 5.6 \\
\hline
\end{tabular}

Keterangan: $\mathrm{KI}=$ tingkat kematangan 1: semua mata buah berwarna hijau, $\mathrm{K} 2=$ tingkat kematangan buah 2: mata buah yang berwarna kuning < 20\%, K3= tingkat kematangan 3: mata buah yang berwarna kuning $40-55 \%$, $\mathrm{K} 4=$ tingkat kematangan 4: mata buah yang berwarna kuning $>90 \%$, tetapi yang berwarna jingga kemerahan $<20 \%$. Angka-angka pada kolom yang sama yang diikuti oleh huruf yang sama tidak berbeda nyata pada taraf $5 \%$ (uji selang berganda Duncan).

Tabel 7. Ekstrapolasi data tinggi bibit asal setek basal daun mahkota nanas Cv. Smooth Cayenne

\begin{tabular}{cc}
\hline Tingkat Kematangan & Waktu Bibit Mencapai $25 \mathrm{~cm}$ (MST) \\
\hline K1 & 58 \\
K2 & 56 \\
K3 & 56 \\
K4 & 52 \\
\hline
\end{tabular}

Keterangan: $\mathrm{KI}=$ tingkat kematangan 1: semua mata buah berwarna hijau, $\mathrm{K} 2=$ tingkat kematangan buah 2: mata buah yang berwarna kuning $<20 \%, \mathrm{~K} 3=$ tingkat kematangan 3: mata buah yang berwarna kuning $40-55 \%$, K4= tingkat kematangan 4: mata buah yang berwarna kuning $>90 \%$, tetapi yang berwarna jingga kemerahan $<20 \%$. 


\section{KESIMPULAN}

Kandungan auksin dan sitokinin endogen tidak berbeda pada semua tingkat kematangan, namun Nisbah $\mathrm{C} / \mathrm{N}$ K3 dan K4 menunjukkan hasil lebih tinggi. Pada semua tingkat kematangan, terbentuknya tunas maksimum terjadi pada 4-6 MST. Tingkat kematangan buah terbaik untuk produksi bibit nanas dengan setek basal daun mahkota adalah K4 (mata buah yang berwarna kuning $>90 \%$, tetapi yang berwarna jingga kemerahan $<20 \%$ ). K4 memiliki kecenderunguan menghasilkan setek hidup, bertunas, dan berakar lebih tinggi. K4 menghasilkan bobot kering tunas tertinggi dan memenuhi standar bibit sertifikasi lebih cepat (52 MST).

\section{UCAPAN TERIMA KASIH}

Ucapan terima kasih disampaikan kepada Pusat Kajian Hortikultura Tropika dan Kemenristekdikti yang memberikan dana untuk kegiatan ini melalui Program Riset Strategis Nasional.

\section{DAFTAR ISI}

Agogbua J. U., J.O Usuji. 2011. Split crown technique for mass propagation of smooth cayenne pineapple in SouthSouth Nigeria. African Journal of Plant Science. 5(10): 591-598.

Adaniya, S., K. Minemoto K, Z. Moromizato, K. Molomura . 2004. The use of CPPU for efficient propagation of pineapple. Scientia Horticulturae. 100: 7-14.

Apriani, P., M.R. Surhartanto. 2015. Peningkatan mutu bibit torbangun (Plectranthus amboinicus Spreng.) dengan pemilihan asal stek dan pemberian auksin. J. Hort. Indonesia. 6(2): 109-115.

Bhardwaj, D.R., V.K. Mishra. 2005. Vegetative propagation of Ulmus villosa: effects of plant growth regulators, collection time, type of donor and position of shoot on adventitious root formation in stem cuttings. New Forests. 9(2): 105-116.
Danu, A. Subiakto, A.Z. Abidin. 2011. Pengaruh umur pohon induk terhadap perakaran setek nyamplung (L.) Calophyllum inophyllum. Jurnal Penelitian Hutan Tanaman. 8(1): 41-49.

Direktorat Perbenihan Hortikultura. 2016. Teknis sertifikasi benih hortikultura. https://ingesz.files.wordpress.com/2017/ 04/2016-teknis-sertifikasi-benihhortikultura.pdf [31 Desember 2018]

Djamhari, S. 2010. Memecahkan dormansi rimpang temulawak (Curcuma xanthorrhiza ROXB) menggunakan larutan atonik dan simulasi perakaran dengan aplikasi auksin. Jurnal Sains dan Teknologi Indonesia. 12(1):66-70.

Elfiani, V. Aryati. 2012. Prospek pengembangan dan penyediaan bibit tanaman nanas. hlm 7-14. Prosiding Seminar dan Kongres Nasional Sumber Daya Genetik. Medan, 12-14 Desember 2012.

Elfiani. 2011. Peningkatan efisiensi produksi bibit nenas hasil kultur jaringan melalui aplikasi GA3 dan pupuk nitrogen pada daun. Tesis. Pascasarjana Institut Pertanian Bogor. Bogor. 60 hal.

[FAOSTAT] Food and Agriculture Organization of the United Nations. 2016. Pineapple. Tersedia pada: http://www.fao. org/statistics/en/ [16 Feb 2017].

Gardner P.F., R.B. Pearce. 1991. Fisiologi Tanaman Budidaya. Universitas Indonesia Press, Jakarta.

Guo, X.F., X.I. Fu , D.K. Zang DK, Yan Ma. 2008. Effect of auxin treatments, cuttings' collection date and initial characteristics on Paeonia 'Yang Fei $\mathrm{Chu} \mathrm{Yu}$ ' cutting propagation. Scientia Horticulturae. 199(2009): 177-181.

Hambrick, C.E., F.T Davies, H.B Perberton . 1991. Seasonal changes in carbohydrate nitrogen levels during field rooting of Rosa multiflora 'Brooks 56' hardwood cuttings. Scientia Horticulturae. 46:137146. 
Hartmann, H.T., D.D. Kester DD, F.T. Davies Jr. 2010. Plant Propagation, Principles and Practice. $8^{\text {th }}$ Edition. Prentice Hall, Inc. New Jersey.

Ling, W.X., Z Zhong . 2012. Seasonal variation in rooting of the cuttings from tetraploid locust in relation to nutrients and endogenous plant hormones of the shoot. Turk J Agric For. 36: 257-266.

Luqmantoro, C., D. Okyanto, A. Soegianto, Kuswanto. 2017. Pengaruh bahan tanamn dan pemberian kombinasi fotohormon terhadap pertumbuhan bibit tanaman nanas (Ananas comosus (L.) Merr. Cv Smooth Cayyen Klon GP 3. Jurnal Produksi Tanaman. 5 (7): 1053-1061.

Magersa, H.G. 2017. Propagation methods of selected horticultural crops by specialized organs: review. J. Hortic. 4(2): $1-4$.

Naibaho, Naekman. 2012. Pengembagan teknologi perbanyakan bibit nenas Smooth Cayenne secara In Vivo melalui aplikasi auksin dan sitokinin. Pascasarjana Institut Pertanian Bogor. Bogor. Bogor. 113 hal.

Nasution, F., S. Hadiati. 2012. The effect of BAP and the level of aging stem on the growth of pineapple (Ananas comosus (L) Merr) stem cutting. ARPN Journal of Agricultural and Biological Science. 7(3): 193-195.

Oktaviana, M.A., R. Linda, Mukarlina. 2015. Pertumbuhan tunas mahkota nenas (Ananas comosus (L.) Merr) secara in vitro dengan penambahan ekstrak tomat (Solanum lycopersicum L.) dan benzil amnio purin (BAP). Protobiont. 4(3): 109-112.
[PKBT] Pusat Kajian Buah Tropika. 2008. Perbanyakan Massal Bibit Nanas dengan Setek Daun. LPPM-IPB, Bogor.

Putri, K.P., Danu. 2014. Pengaruh umur bahan setek dan zat pengatur tumbuh terhadap keberhasilan setek kemenyan (Dryand) Styrax benzoin. Jurnal Penelitian Hutan Tanaman.11(3): 141-147.

Py, C., J.J. Lacoeuilhe, C. Teisson. 1987. The Pineapple, Cultivation and Uses. Paris (FR): G.P. Maisonneuve and Larose.

Rupina, P., Mukarlina, R. Linda. 2015. Kultur meristem mahkota nanas (Ananas comosus (L.) Merr) dengan penambahan ekstrak tauge dan benzyl amino purin (BAP). Protobiont. 4(3) : 31-35.

Shiyam, J.O., W.B. Binang, J.C. Obiefuna 2016. Suckering and survival capacity of pineapple (Ananas comosus L. Merr) propagules in selected potting substrates. Journal of Natural Sciences Research. 6(5):95-99.

Tassew, A.A. 2014. Evaluation of leaf bud cuttings from different sized crowns for rapid propagation of pineapple (Ananas Comosus L. [Merr.]). Journal of Biology, Agriculture and Healthcare. 4(27): 1-7.

Weerasinghe, S.S., A.U. Siriwardana. 2006. Fast propagation of pineapple (Ananas comosus) with stem cuttings. The J. Agricultural Sciences. 2(2): 1-5. 